\title{
THE INFLUENCE OF TELEVISION ON CHILDREN'S ASSIMILATION OF STEREOTYPES OF GENDER ROLES
}

\section{Anastasia Titova 1}

\section{Abstract}

The problem of assimilation of gender roles by children and adolescents in the family and school is multi-stage, since sexual differentiation is one of those universal phenomena that, one way or another, study all the Sciences about man and for man. Modern gender studies allow us to establish quite accurately when the formation of stereotypes of male and female behavior begins. This happens around the time when the child moves from simple imitative action games with objects to story games with other children. Children often learn gender role stereotypes from books, songs, television and movies. Television, however, is perhaps the most influential form of media.

Key words: Television, child, TV, family, stereotypes, gender roles, people, woman, man, influence.

doi: http://doi.org/10.15350/F_6/29

Дети часто усваивают стереотипы гендерных ролей из книг, песен, телевидения и фильмов. Телевидение, однако, является, пожалуй, самой влиятельной формой СМИ. Исследования в области телевизионного просмотра и социализации детей показывают, что телевидение оказывает большое влияние на жизнь детей. Дошкольники проводят в среднем около 30 часов в неделю за просмотром телевизора; некоторые тратят больше времени на просмотр телевизора, чем на что-либо еще, кроме сна. Исследования показывают, что к тому времени, когда детям исполняется 16 лет, они проводят больше времени у телевизора, чем в школе. В результате дети подвергаются воздействию около 20000 рекламных объявлений в год. К тому времени, когда ребенок закончит среднюю школу, он будет свидетелем 13000 насильственных смертей по телевидению.

Телевидение влияет как на просоциальное, так и на антисоциальное поведение детей, а также на их отношение к расе и полу.

Развитие детей дети растут и развиваются, они усваивают информацию и приобретают знания в быстром темпе. Развивая свои когнитивные способности, они усваивают новую информацию и приспосабливают ее к тому, что они уже знают. Представления детей о том, как устроен мир, проистекают из их опыта, а также из установок и поведения, которые они видят вокруг себя. Маленький ребенок, который верит, что только женщины являются медсестрами, а только мужчины-врачами, возможно, развил это понимание, потому что первым врачом, которого он увидел, был мужчина, которому помогала женщина-медсестра. Эта идея "мужчина как врач, женщина как медсестра", возможно, получила дальнейшее развитие благодаря родителям, книгам, разговорам с друзьями и телевидению. Если ребенок часто сталкивается с такими гендерными предубеждениями и гендерными стереотипами, эти знания будут включены в будущие представления. Помня о том, что маленькие дети с развитым умом смотрят много часов телевизор, и вспоминая, как телевидение укрепляет гендерные стереотипы, неудивительно, что у детей развиваются стереотипные убеждения.

${ }^{1}$ Anastasia Titova, student, Voronezh state university, Russia. 
Из различных факторов, которые помогают формировать гендерно-типизированное поведение, ролевые модели и имитация чрезвычайно влиятельны. Исследования показывают, что дети, которые смотрят насильственные программы по телевидению, будут вести себя более агрессивно со сверстниками. Верно также и то, что дети, которые смотрят просоциальное поведение по телевизору, с большей вероятностью сами демонстрируют такие типы поведения. Маленькие дети будут имитировать и повторять поведение, которое они видят по телевизору. Следовательно, дети могут демонстрировать эти гендерные предубеждения и развивать гендерные предубеждения, которые они видят по образцу телевидения.

Развитие самостоятельности, инициативы и чувства трудолюбия имеет решающее значение для позитивного развития маленьких детей. Дети, которые наблюдают за женскими персонажами в телевизионных программах, которые пассивны, нерешительны и подчинены мужчинам, и которые видят, что это усиливается их окружением, вероятно, поверят, что это подходящий способ для женщин вести себя. У девочек меньше шансов развить самостоятельность, инициативу и трудолюбие, если они редко видят, как эти черты моделируются. Точно так же, поскольку мужские персонажи телевизионных программ с большей вероятностью будут показаны в роли лидеров и демонстрировать напористое, решительное поведение, дети узнают, что это подходящий способ для мужчин вести себя.

Исследования показывают, что телевидение оказывает социализирующее влияние на детей в отношении их отношения к гендерным ролям. Стереотипы гендерной роли, которые можно увидеть по телевидению, в свою очередь, усиливаются родителями, друзьями и школой, способствуя пониманию ребенком того, что значит быть мужчиной или женщиной в обществе. Телевидение посылает убедительные сообщения об одобренных обществом гендерных ролях, которые часто стереотипны, предвзяты и устарели. По мере того как дети продолжают развиваться и расти, они подвергаются все большему количеству примеров таких гендерных предубеждений и стереотипов.

Традиционные гендерные роли, в которых мужчин поощряют быть решительными и проявлять лидерские качества, в то время как женщин поощряют быть почтительными и зависимыми, никому не приносят пользы, особенно женщинам. Они препятствуют полному спектру самовыражения и достижений. Детям должно быть позволено развивать чувство собственного достоинства в условиях гендерного равенства, которое побуждает каждого в полной мере чувствовать себя частью общества.

References:

[1] Gubanov I.A., Krylova I.L., Tikhonova V.L. Psychological aspects of modern human behavior. - M.: Thought, 1976. - $360 \mathrm{p}$.

[2] Bubnov Yu.M. sociology essays on gender relations / Y.M. Bubnov.- Minsk: Law and Economics, 2007 - $272 \mathrm{p}$. 